\title{
KONSEP PROSEDUR PELAKSANAAN DIVERSI PADA TAHAP \\ PENYIDIKAN DALAM PENYELESAIAN TINDAK \\ PIDANA YANG DILAKUKAN OLEH ANAK
}

\author{
Achmad Ratomi \\ Fakultas Hukum Universitas Lambung Mangkurat \\ Jl. Brigjen. H. Hasan Basri, Kotak Pos 219, Banjarmasin 70123, Kalimantan Selat \\ Email: ratomi79ach@gmail.com
}

\begin{abstract}
The purpose of this study was to analyze the implementation of the concept of diversion procedure at the investigation stage in the completion of the crime by children.

This study uses a kind of normative legal research, which is a process to find the rule of law, principles of law and legal doctrines in order to answer the legal issues faced in order to obtain the arguments, theories or concepts as prescriptions in solving the problem.

The concept of diversion at the stage of implementation procedures in the completion of the investigation of criminal acts committed by children there are three forms, namely: First, Police Conference. The party consisted of the police and offender. Type of crime is violations and minor crime. Second, the Family Conference. The parties involved are the police, offender and /or parent/guardian, and the supervising community. Type of crime is a minor crime, crime without victim and crime the value of the losses of victims not more than the provincial minimum wage. Third, Public Conference. The parties involved are the police, offender and/or parent/guardian, the victim and/or the parent/guardian and supervising community and society. Type of crime is a crime punishable by prison of less than 7 (seven) years and not a repetition of crime.
\end{abstract}

Key words: diversion, investigation, crime by child

\begin{abstract}
Abstrak
Tujuan dari penelitian ini adalah untuk menganalisis tentang konsep prosedur pelaksanaan diversi pada tahap penyidikan dalam penyelesaian tindak pidana yang dilakukan oleh anak.

Penelitian ini menggunakan jenis penelitian hukum normatif, yaitu suatu proses untuk menemukan aturan hukum, prinsip-prinsip hukum maupun doktrin-doktrin hukum guna menjawab isu hukum yang dihadapi sehingga diperoleh argumentasi, teori atau konsep baru sebagai preskripsi dalam menyelesaikan masalah.

Konsep prosedur pelaksanaan diversi pada tahap penyidikan dalam penyelesaian tindak pidana yang dilakukan oleh anak terdapat tiga bentuk, yaitu: Pertama, Musyawarah Polisi. Para pihak hanya terdiri atas polisi dan pelaku. Jenis tindak pidananya adalah pelanggaran dan tindak pidana ringan. Kedua, Musyawarah Keluarga Para pihak yang terlibat adalah polisi, pelaku dan/atau orangtua/walinya, dan pembimbing kemasyarakatan. Jenis tindak pidananya adalah tindak pidana ringan, tindak pidana tanpa korban dan tindak pidana yang nilai kerugian korban tidak lebih dari nilai upah minimum propinsi setempat. Ketiga, Musyawarah Masyarakat Para pihak yang terlibat adalah polisi, pelaku dan/atau orangtua/walinya, korban dan/atau orangtua/ walinya dan pembimbing kemasyarakatan serta masyarakat. Jenis tindak pidananya adalah tindak pidana yang diancam dengan pidana penjara di bawah 7 (tujuh) tahun dan pelaku bukan melakukan pengulangan tindak pidana.
\end{abstract}

Kata kunci: diversi, penyidikan, tindak pidana oleh anak 


\section{Latar Belakang}

Anak sebagai manusia yang masih dalam taraf pertumbuhan dan perkembangan sangat rentan melakukan suatu perbuatan yang menurut mereka perbuatan tersebut adalah suatu hal yang biasa, namun kenyataan secara yuridis perbuatan yang dilakukan oleh anak itu termasuk kategori tindak pidana. Misalnya anak yang bermain ketangkasan di arena permainan anak-anak yang dalam bermainnya memperoleh bonus atau imbalan baik berupa uang maupun barang. Di pandangan anak perbuatan tersebut adalah suatu permainan, sedangkan dalam perspektif hukum itu adalah suatu tindak pidana.

Penyimpangan tingkah laku atau perbuatan melanggar hukum yang dilakukan oleh anak, disebabkan oleh berbagai faktor, antara lain adanya dampak negatif dari perkembangan pembangunan yang cepat, arus globalisasi di bidang komunikasi dan informasi, kemajuan ilmu pengetahuan dan teknologi serta perubahan gaya dan cara hidup sebagian orang tua. Semua fakta tersebut telah membawa perubahan sosial yang mendasar dalam kehidupan masyarakat yang sangat berpengaruh terhadap nilai dan perilaku anak. Selain itu, anak yang kurang atau tidak memperoleh kasih sayang, asuhan, bimbingan dan pembinaan dalam pengembangan sikap, perilaku, penyesuaian diri, serta pengawasan dari orang tua, wali, atau orang tua asuh akan mudah terseret dalam arus pergaulan masyarakat dan lingkungannya yang kurang sehat dan merugikan perkembangan pribadinya. $^{1}$

Perlakuan penegak hukum terhadap anak yang di duga melakukan tindak pidana seringkali bersifat sangat represif. Proses peradilan terhadap anak seringkali kehilangan makna esensinya, yaitu sebagai mekanisme yang harus berakhir dengan upaya untuk melindungi kepentingan terbaik bagi anak (the best interest of child). Peradilan pidana anak seringkali merupakan proses yang hanya berorientasi pada penegakan hukum secara formal dan tidak berorientasi pada kepentingan anak. ${ }^{2}$

Perlakuan-perlakuan yang cenderung membekaskan stigma atas diri anak lebih mengedepan dibandingkan perlakuan aparat penegak hukum yang mencerminkan perlindungan hak-hak anak yang melakukan tindak pidana. Anak yang terlibat dalam proses peradilan pidana sering memperoleh perlakuan yang buruk bahkan dalam beberapa hal telah diperlakukan lebih buruk bila dibandingkan dengan orang dewasa yang berada dalam situasi yang sama. Mayoritas dari anak yang melakukan tindak pidana mengalami tindak kekerasan selama dalam proses peradilan pidana. ${ }^{3}$

1 Penjelasan Umum Undang-Undang Nomor 3 Tahun 1997 tentang Pengadilan Anak.

2 Koesno Adi, Kebijakan Kriminal dalam Sistem Peradilan Pidana yang Berorientasi pada Kepentingan Terbaik Bagi Anak, Pidato Pengukuhan Jabatan Guru Besar dalam bidang Ilmu Hukum Pada Fakultas Hukum Universitas Brawijaya Malang, 2009, hlm. 6.

3 Ibid, hlm. 8 . 
Berdasarkan data Komisi Perlindungan Anak Indonesia (KPAI) pada Juli 2009, Indonesia merupakan negara yang paling banyak memidanakan anak yaitu sudah ada 6.000 anak. Sementara, 3.800 anak di antaranya mendekam di lembaga pemasyarakatan (Lapas). ${ }^{4}$ Seharusnya tidak semua anak dimasukkan dalam lembaga pemasyarakatan Bukan proses pembelajaran mental yang mereka dapatkan, tapi pembelajaran secara internal dari narapidana yang lebih dewasa. Padahal di Indonesia hanya ada 16 Lembaga Pemasyarakatan Anak (Lapas Anak).

Fenomena di atas menunjukkan bahwa penanganan terhadap anak sebagai pelaku tindak pidana oleh aparat penegak hukum melalui proses peradilan selama ini cenderung merugikan masa depan anak. Keadaan tersebut bukan saja sangat memprihatinkan, namun sangat mengkhawatirkan karena hal itu menggambarkan bahwa sesungguhnya penanganan terhadap anak yang diduga melakukan tindak pidana belum benar-benar mencerminkan perlindungan anak.

Anak-anak selama dalam proses pemeriksaan (mulai dari kepolisian, kejaksaan sampai pengadilan) merasa kurang dihargai, perlakuan-perlakuan para petugas cenderung membekaskan citra negatif dalam benak mereka (stigmatisasi). Perlakuan petugas tersebut menjadi salah satu sebabnya adalah karena anak-anak itu merasa ditangani oleh petugas hukum yang kurang memahami masalah mereka sebagai anak. Persayaratan adanya profesionalisme penegak hukum di bidang anak tidak dipenuhi. Persyaratan formal lebih dikedepankan daripada persyaratan substansial dalam penunjukan penegak hukum khusus anak. Legitimasi mereka sebagai penegak hukum di bidang anak hanya semata-mata didasarkan atas Surat Penunjukan sebagai Polisi khusus Anak, Jaksa Khusus Anak, Hakim Khusus Anak, dan bukannya persyaratan subsatnsial seperti yang diamanatkan oleh Undang-Undang Nomor 3 Tahun 1997 tentang Pengadilan Anak (UUPA) $)^{5}$ yang telah diganti dengan UndangUndang Nomor 11 Tahun 2012 tentang Sistem Peradilan Pidana Anak (UU SPPA). ${ }^{6}$ Padahal melalui UUPA diharapkan petugas yang bertindak sebagai penyidik, penuntut umum, dan hakim benar-benar menguasai dan memahami masalah anak, sehingga dalam proses penanganannya tidak menimbulkan gangguan baik secara fisik maupun mental terhadap masa depan anak.

Padahal jika berpedoman kepada The United Nations Standard Minimum Rules for Administration of Juvenile Justice - the Beijing Rules (Peraturan Standar Minimum

4 Tim KPAI: Indonesia Negara Terbanyak Memidana Anak, Kompas, 16 Juli 2009.

5 Paulus Hadisuprapto, Peradilan Restotarif: Model Peradilan Anak Indonesia Masa Datang, Pidato Pengukuhan Guru Besar dalam Bidang Kriminologi pada Fakultas Hukum Universitas Diponegoro, Semarang, 18 Februari 2006, hlm. 22.

6 Berdasarkan Pasal 108 Undang-Undang Nomor 11 Tahun 2012 tentang Sistem Peradilan Pidana Anak, menyebutkan bahwa "Undang-Undang ini mulai berlaku setelah 2 (dua) tahun terhitung sejak tanggal diundangkan”. UU ini disahkan pada tanggal 30 Juli 2012. 
PBB untuk Pelaksanaan Peradilan Anak Peraturan Beijing), yang disahkan melalui Resolusi Majelis PBB No. 40/33 Tanggal 29 November 1985, maka tujuan dari peradilan anak sebagaimana disebutkan dalam Rule 5.1 adalah "The juvenile justice system shall emphasize the well-being of the juvenile and shall ensure that any reaction to juvenile offenders shall always be in proportion to the circumstances of both the offenders and the offence". Berdasarkan ketentuan tersebut dipahami bahwa sistem peradilan anak harus lebih menekankan pada kesejahteraan anak dan harus dipastikan bahwa seluruh penanganan terhadap anak harus selalu sesuai dengan keadaan, baik keadaan dari pelaku maupun keadaan dari pelanggaran/kejahatan).

Berkaitan dengan tujuan tersebut, maka ada satu model penyelesaian perkara pidana anak tanpa harus melalui proses peradilan, sebagaimana diatur dalam Rule. 11 The Beijing Rules yang berbunyi :

\subsection{Consideration shall be given, wherever} appropriate, to dealing with juvenile offenders without resorting to formal trial by the competent authority, referred to in rule 14.1 below;

(Terjemahan bebas: Pertimbangan harus diberikan kapan saja diperlukan untuk menangani anak tanpa harus menyerahkannya pada pengadilan formal oleh lembaga yang berwenang, seperti yang diatur dalam aturan 14.1 dibawah).
11.2 The police, the prosecution or other agencies dealing with juvenile cases shall be empowered to dispose of such cases, at their discretion, without recourse to formal hearings, in accordance with the criteria laid down for that purpose in the respective legal system and also in accordance with the principles contained in these Rules;

(Terjemahan bebas: Pihak kepolisian, kejaksaan atau lembaga-lembaga lain yang menangani tindak pidana yang dilakukan oleh anak harus diberikan wewenang untuk menyelesaikan perkara-perkara tersebut atas dasar keputusan yang mereka ambil tanpa harus menyerahkannya kepada persidangan formal sesuai dengan kriteria yang diberikan untuk tujuan tersebut dalam sistem hukum masingmasing serta sesuai dengan prinsipprinsip yang termuat dalam Aturan ini).

11.3 Any diversion involving referral to appropriate community or other services shall require the consent of the juvenile, or her or his parents or guardian, provided that such decision to refer a case shall be subject to review by a competent authority, upon application;

(Terjemahan bebas: Setiap pengalihan yang berupa rujukan kepada layanan mayarakat yang tepat dan layanan lainnya harus mendapatkan persetujuan 
dari anak tersebut, atau orangtua atau pengasuhnya, dengan syarat bahwa pada saat dilaksanakan, keputusan itu bisa ditinjau kembali oleh pejabat yang berwenang).

11.4 In order to facilitate the discretionary disposition of juvenile cases, efforts shall be made to provide for community programmes, such as temporary supervision and guidance, restitution, and compensation of victims.

(Terjemahan bebas: Dalam rangka memfasilitasi kebijakan melepaskan anak, harus dilakukan upaya-upaya untuk melengkapi program-program masyarakat, seperti pengawasan dan bimbingan sementara, ganti rugi dan kompensasi bagi para korban).

Ketentuan tersebut di atas lebih dikenal dengan istilah "diversi”. Menurut Jack E. Bynum "Diversion is an attempt to divert, or channel out, youthful offenders from the juvenile justice system". ${ }^{7}$ Berdasarkan ketentuan tersebut dipahami bahwa diversi adalah sebuah tindakan untuk mengalihkan atau menempatkan pelaku anak dari sistem peradilan anak. Sedangkan Paulus Hadisuprapto mendefinisikan diversi sebagai suatu mekanisme yang memungkinkan anak dialihkan dari proses peradilan menuju proses pelayanan sosial. ${ }^{8}$ Dengan demkian, maka diversi merupakan mekanisme pengalihan perkara dari proses formal (hukum) ke proses informal (sosial).

Keberadaan diversi di Indonesia telah diakui melalui UU SPPA yang disahkan pada tanggal 30 Juli 2012 dan mulai berlaku efektif 2 (dua) tahun kemudian. Pasal 7 ayat (1) UU SPPA menyatakan bahwa "Pada tingkatan penyidikan, penuntutan dan pemeriksaan perkara anak di pengadilan negeri wajib diupayakan diversi". Syarat atau kriteria tindak pidana yang dapat dilakukan diversi adalah sebagaimana dijelaskan dalam Pasal 7 ayat (2) UU SPPA yang berbunyi "Diversi dilaksanakan dalam hal tindak pidana yang dilakukan:

a. diancam dengan pidana penjara di bawah 7 (tujuh) tahun; dan

b. bukan merupakan pengulangan tindak pidana".

Pengaturan prosedur pelaksanaan diversi sebagaimana yang terdapat dalam Pasal

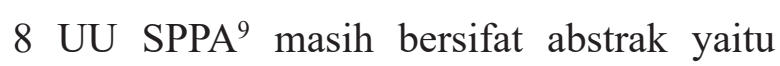
hanya menyebutkan bentuk diversi melalui musyawarah berdasarkan Keadilan Restoratif yang melibatkan pelaku dan keluarganya, korban dan keluarganya, Pembimbing Kemasyarakatan, dan Pekerja Sosial Profesional serta masyarakat.

7 Ibid.

8 Paulus Hadisuprapto, Delinkuensi Anak: Pemahaman dan Penanggulangannya, Bayumedia Publishing, Malang, 2008, hlm. 131.

9 Pasal 8 UU SPPA menjelaskan bahwa proses Diversi dilakukan melalui musyawarah dengan melibatkan Anak dan orang tua/Walinya, korban dan/atau orang tua/Walinya, Pembimbing Kemasyarakatan, dan Pekerja Sosial Profesional berdasarkan pendekatan Keadilan Restoratif. 


\section{Pembahasan}

Berdasarkan pada Pasal 7 ayat (1)

UU SPPA, pelaksanaan diversi ini harus dilakukan pada setiap tingkatan dalam proses peradilan pidana anak (mulai penyidikan oleh kepolisian, penuntutan oleh penuntut umum dan pemeriksaan di pengadilan oleh hakim).

Diberikannya kewenangan kepada kepolisian selaku penyidik untuk melakukan diversi dalam penyelesaian perkara tindak pidana yang dilakukan oleh anak lebih didasarkan pada kedudukan kepolisian sebagai lembaga penegak hukum yang pertama dan langsung bersinggungan dengan masyarakat, polisi pada dasarnya mempunyai potensi yang demikian besar untuk merubah kultur masyarakat. Kewenangan dan otoritas polisi apabila dikemas secara dinamis akan menjadi sarana bagi polisi dalam membangun masyarakat. Dalam konteks ini, pengalaman para bobby di Inggris dapat menjadi acuan. Istilan bobby untuk menunjuk pada sosok polisi di Inggris berasal dari nama Robert Peel sebagai sosok polisi yang selalu ramah, tidak memihak dan penuh humor. Sikap polisi yang demikian inilah yang pada akhirnya ter-internalisasi-kan ada masyarakat Inggris, sehingga masyarakat Inggris berkembang menjadi masyarakat yang tertib dan teratur. ${ }^{10}$

Ada beberapa keuntungan yang akan diperoleh jika diversi dilakukan pada tahap penyidikan oleh kepolisian, yaitu: ${ }^{11}$
1. Kepolisian merupakan satu-satunya lembaga penegak hukum dalam sub sistem peradilan pidana yang mempunyai jaringan hingga tingkat kecamatan. Dengan demikian, secara structural lembaga kepolisian merupakan satusatunya lembaga penegak hukum yang paling dekat dan paling mudah dijangkau oleh masyarakat. Dengan potret kelembagaan yang demikian, kepolisian merupakan lembaga penegak hukum yang paling memungkinkan untuk memiliki jaringan sampai di tingkat yang paling bawah (tingkat desa). Salah satu lembaga yang dibentuk oleh kepolisian pada tingkat desa/kelurahan adalah Badan Kemitraan Polisi dan Masyarakat (BKPM).

2. Secara kuantitas aparat kepolisian jauh lebih banyak dibandingakan dengan aparat penegak hukum yang lainnya, sekalipun juga disadari bahwa tidak setiap aparat kepolisian mempunyai komitmen untuk menangani tindak pidana yang dilakukan oleh anak, tetapi ketersediaan personil yang cukup memadai juga akan sangat membantu proses penyelesaian tindak pidana yang dilakukan oleh anak.

3. Oleh karena lembaga kepolisian merupakan aparat penegak hukum pertama yang bergerak dalam proses peradilan pidana, maka diversi di

10 Koeno Adi, Diversi Sebagai Upaya Alternatif Penanggulangan Tindak Pidana Narkotika Oleh Anak, UMM Press, Malang, 2009, hlm. 111.

11 Ibid, hlm. 112-113. 
tingkat kepolisian mempunyai makna memberikan jaminan kepada anak untuk sedini mungkin dihindarkan dari bersinggungan dengan proses peradilan pidana. Dengan demikian, dampak negatif akibat anak bersinggungan dengan aparat penegak hukum dapat diminimalisir.

Proses diversi pada dasarnya merupakan upaya pengalihan dari proses peradilan pidana menuju penyelesaian secara musyawarah, yang pada dasarnya merupakan jiwa dari bangsa Indonesia, untuk menyelesaikan permasalahan dengan cara kekeluargaan untuk mencapai mufakat. Hal ini sesuai dengan bunyi Sila ke-4 Pancasila yang berbunyi "Kerakyatan yang Dipimpin oleh Hikmat Kebijaksanaan dalam Permusyawaratan/ Perwakilan".

Inti dari makna Sila ke-4 Pancasila diatas dalam kaitannya dengan diversi adalah dianutnya prinsip musyawarah mufakat dalam setiap pengambilan keputusan dalam rangka penyelesaian perkara pidana yang dilakukan oleh anak. Musyawarah mufakat merupakan proses membahas persoalan secara duduk bersama dengan melibatkan pihak-pihak yang terkait demi mencapai kesepakatan bersama. Musyawarah mufakat dilakukan sebagai cara untuk mendapatkan keputusan yang samasama menguntungkan kedua belah pihak sehingga tidak ada pihak yang dirugikan. Dengan musyawarah mufakat diharapkan dua atau beberapa pihak yang berbeda pendapat tidak terus bertikai dan mendapat jalan tengah. Karena itu, dalam proses musyawarah mufakat diperlukan kerendahan hati dan keikhlasan diri serta membuang ego masingmasing. Dalam kehidupan kemasyarakatan, musyawarah mufakat memiliki beberapa manfaat langsung, yaitu sebagai berikut :

1. Musyawarah mufakat merupakan cara yang tepat untuk mengatasi berbagai silang pendapat.

2. Musyawarah mufakat berpeluang mengurangi penggunaan kekerasan dalam memperjuangkan kepentingan.

3. Musyawarah mufakat berpotensi menghindari dan mengatasi kemungkinan terjadinya konflik.

Budaya musyawarah mufakat ini memiliki landasan filosofis dan teologis yang mengarah kepada pemulihan harkat dan martabat semua pihak yang terlibat, mengganti suasana konflik dengan perdamaian (asas silahturahmi), menghapus hujat menghujat dengan pemaafan, menghentikan tuntut menuntut dan salah menyalahkan (asas saling memaafkan dan memohon ampunan kepada Tuhan). Klarifikasi yang diinginkan tidak melalui meja pengadilan, melainkan melalui meja perdamaian dan perundingan (asas musyawarah). ${ }^{12}$

Penyelesaian perkara melalui musyawarah diarahkan pada harmonisasi atau

12 Adi Sulistiyono, "Merasionalkan Budaya Musyawarah Untuk Mengembangkan Penggunaan Penyelesaian Sengketa Win-Win Solution", Orasi Ilmiah Dalam Rangka Dies Natalis XXIX Universitas Sebelas Maret Disampaikan Pada Sidang Senat Terbuka Universitas Sebelas Maret Tanggal 12 Maret 2005 , hlm. 12 . 
kerukunan dalam masyarakat serta tidak memperuncing keadaan, dengan sedapat mungkin menjaga suasana perdamaian. Hal ini tentu sejalan dengan beberapa prisip yang melekat pada konsep diversi, misalnya:

1. Konsep diversi bertujuan menciptakan perdamaian antara pelaku dan korban dengan cara memberikan ganti rugi ataupun dengan permintaan maaf dan dianggap tidak ada konflik lagi, serta permintaan penyesalan dan pelaku tidak akan mengulangi perbuatan jahatnya.

2. Program-program diversi dapat berupa; cukup dengan pemberian peringatan, pembinaan keterampilan, bimbingan ataupun konseling (pemberian nasihat).

3. Kasus-kasus yang dilakukan diversi biasanya kasus yang tidak berat dan tidak membahayakan masyarakat, dan ada kedekatan hubungan antara pelaku dan korban.

Diversi melalui keadilan restoratif yang sepaham dengan budaya bangsa Indonesia sedikitnya memiliki keuntungan sebagai berikut:

1. Dapat mengurangi kemacetan dan penumpukan perkara di pengadilan. Banyaknya kasus yang diajukan ke pengadilan menyebabkan proses berperkara seringkali berkepanjangan dan memakan biaya yang tinggi serta sering memberikan hasil yang kurang memuaskan.

2. Meningkatkan keterlibatan masyarakat atau memberdayakan pihak-pihak yang bersengketa dalam proses penyelesaian sengketa.

3. Memperbesar peluang masyarakat untuk mendapatkan keadilan.

4. Memberi kesempatan bagi tercapainya penyelesaian sengketayang menghasilkan keputusan yang dapat diterima oleh semua pihak. Sehingga para pihak tidak menempuh upaya banding dan kasasi.

5. Penyelesaian perkara lebih cepat dan biaya murah.

6. Bersifat tertutup atau rahasia, sehingga mengurangi rasa malu keluarga.

7. Lebih tinggi tingkat kemungkinan untuk melaksanakan kesepakatan yang dikarenakan keputusan yang diambil merupakan kehendak para pihak. Sehingga hubungan pihakpihak bersengketa di masa depan masih dimungkinkan terjalin dengan baik.

8. Mengurangi merebaknya mafia hukum baik di tingkat penyidikan, penututan, pengadilan maupun pada tingkat pelaksanaan putusan pengadilan.

Diversi sebagai usaha mengajak masyarakat untuk taat dan menegakan hukum negara, pelaksanaanya tetap mempertimbangkan rasa keadilan sebagai prioritas utama disamping pemberian kesempatan kepada pelaku untuk menempuh jalur non pidana seperti ganti rugi, kerja sosial atau pengawasan orang tuanya. Diversi tidak bertujuan mengabadikan hukum dan keadailan sama sekali, akan tetapi berusaha memakai unsur pemaksaan seminimal mungkin untuk 
membuat orang mentaati hukum. Oleh karena itu, sangat diperlukan peran serta semua pihak dalam rangka mewujudkan hal tersebut. Proses itu harus bertujuan pada terciptanya Keadilan Restoratif, baik bagi Anak maupun bagi korban. Keadilan Restoratif merupakan suatu proses Diversi, yaitu semua pihak yang terlibat dalam suatu tindak pidana tertentu bersama-sama mengatasi masalah serta menciptakan suatu kewajiban untuk membuat segala sesuatunya menjadi lebih baik dengan melibatkan korban, Anak, dan masyarakat dalam mencari solusi untuk memperbaiki, rekonsiliasi, dan menenteramkan hati yang tidak berdasarkan pembalasan.

Selain para pihak yang berperkara (pelaku dan korban), peranan masyarakat sangat menentukan juga dalam terwujudnya diversi ini. Di dalam UU SPPA peran masyarakat dapat dilihat dalam Pasal 93 huruf $d$ dan huruf e yang berbunyi "Masyarakat dapat berperan serta dalam pelindungan Anak mulai dari pencegahan sampai dengan reintegrasi sosial Anak dengan cara: (d) berpartisipasi dalam penyelesaian perkara Anak melalui Diversi dan pendekatan Keadilan Restoratif; dan (e) berkontribusi dalam rehabilitasi dan reintegrasi sosial Anak, Anak Korban dan/atau Anak Saksi melalui organisasi kemasyarakatan;

Ini artinya masyarakat yang bukan sebagai pelakuatau korban diikutsertakan dalam proses penyelesaian perkara pidana yang dilakukan oleh anak. Keterlibatan masyarakat ini sangat membantu dalam menciptakan suasana yang lebih aman dan tenteram dalam pergaulan bermasyarakat. Anak yang melakukan tindak pidana tidak hanya merasa bertanggung jawab terhadap korban saja melainkan juga merasa bertanggung jawab atas lingkungannya.

Polisi selaku pemangku kewenangan diversi diberi tanggung jawab untuk menentukan kebijakan mekanisme yang akan ditempuh dalam menerapkan diversi. Menurut penulis ada 3 (tiga) bentuk konsep mekanisme pelaksanan diversi oleh kepolisian, yaitu:

\section{A. Musyawarah Polisi}

Pihak yang terlibat dalam proses ini adalah polisi dan anak (pelaku). Jenis tindak pidana yang dapat diselesaikan melalui mekanisme ini pada umumnya tindak pidana berupa pelanggaran dan tindak pidana ringan. Tindak pidana tersebut baik yang terdapat dalam KUHP maupun yang terdapat di luar KUHP. Hal ini sesuai dengan ketentuan yang terdapat dalam Pasal 9 ayat (2) huruf a dan huruf b UU SPPA.

Pada saat polisi mengetahui telah terjadinya tindak pidana baik yang diketahui secara langsung (tertangkap tangan) atau melalui laporan atau pengaduan dari korban atau masyarakat, maka saat itu juga polisi dapat memanggil anak yang diduga melakukan tindak pidana untuk dimintai keterangan atas perbuatan yang telah dilakukannya. Polisi memberikan kesempatan kepada anak untuk menceritakan secara jelas dan lengkap atas perbuatan yang telah dilakukannya. Setelah polisi mendengarkan keterangan dari si 
anak, selanjutnya polisi dapat menyimpulkan apakah anak tersebut terbukti bersalah telah melakukan tindak pidana yang dituduhkan. Jika anak tersebut tidak terbukti maka polisi harus melepaskannya, namun jika anak tersebut terbukti bersalah, maka polisi dapat memberikan sanksi kepada anak tersebut. Atau polisi dapat langsung memberikan sanksi jika anak telah mengakui perbuatannya.

Sanksi yang dapat diberikan oleh polisi pada anak yang melakukan tindak pidana adalah peringatan informal (informal caution). Peringatan informal yaitu berupa peringatn lisan dan peringatan tertulis. Peringatan lisan berupa pemberian nasihat kepada anak agar tidak melakukan tindak pidana lagi dan menjauhi perbuatan yang negatif. Sedangkan peringatan tertulis merupakan teguran keras tidak hanya sekadar memberi nasihat melainkan anak diberi peringatan keras, salah satunya dengan cara anak harus meminta maaf kepada korban. Peringatan informal itu hanya dapat diberikan kepada anak yang pertama kali melakukan tindak pidana (bukan pengulangan tindak pidana). Dan tidak perlu mendapatkan persetujuan dari korban atau/ keluarganya jika korban masih anak di bawah umur. Peringatan informal tersebut tidak dicatat dalam suatu kesepakatan dan tidak perlu dimintakan penetapan ke pengadilan negeri.

\section{B. Musyawarah Keluarga}

Para pihak yang terlibat dalam proses diversi adalah polisi, pelaku dan/atau orangtua/ walinya, dan pembimbing kemasyarakatan. Jenis tindak pidana yang dapat diselesaikan melalui mekanisme ini adalah tindak pidana ringan, tindak pidana tanpa korban dan tindak pidana yang nilai kerugian korban tidak lebih dari nilai upah minimum propinsi setempat. Tindak pidana ringan tersebut harus tindak pidana ringan yang perilaku anak pada saat melakukannya sangat membahayakan orang lain dan tindak pidana ringan yang merupakan pengulangan atau sebelumnya telah diberi peringatan informal.

Prosedur yang harus dilakukan oleh polisi dalam mekanisme ini adalah hampir sama dengan prosedur yang terdapat pada musyawarah polisi. Namun karena di dalam musyawarah keluarga ini melibatkan kehadiran orangtua/wali dari anak dan pembimbing kemasyarakatan, maka polisi memberikan kesempatan kepada orangtua/wali dari anak untuk menceritakan latar belakang kehidupan anak dan kegiatan keseharian anak baik di rumah maupun di masyarakat. Selanjutnya kesempatan diberikan pula kepada pembimbing kemasyarakatn untuk memberikan pertimbangan yang sifatnya tidak sama dengan hasil penelitian kemasyarakatan. Kedudukan pembimbing kemasyarakatan disini lebih bersifat sebagai ahli yang dapat memberikan rekomendasi tentang sanksi apa yang cocok untuk diberikan kepada anak. Jadi tugas pembimbing kemasyarakatan tidak bersifat formal sebagaimana yang diatur dalam Pasal 65 huruf a UU SPPA yang berbunyi "Pembimbing Kemasyarakatan 
bertugas: membuat laporan penelitian kemasyarakatan untuk kepentingan Diversi, melakukan pendampingan, pembimbingan, dan pengawasan terhadap Anak selama proses Diversi dan pelaksanaan kesepakatan, termasuk melaporkannya kepada pengadilan apabila Diversi tidak dilaksanakan”.

Bentuk sanksi yang dapat diberikan dalam bentuk mekanisme melalui musyawarah keluarga ini adalah peringan formal (formal caution). Peringatan formal ini dapat berupa:

a. Menyerahkan kembali kepada orangtua/ walinya;

b. Permintaan maaf kepada korban dimuka umum;

c. Rehabilitasi medis dan psikososial;

d. Perbaikan akibat tindak pidana

e. Pembayaran ganti rugi.

Perkara anak menjadi berakhir seiring dengan pemberian peringatan formal. Peringatan formal ini perlu dicatat dalam buku catatan kepolisian dan tidak perlu disampaikan ke ketua Pengadilan Negeri untuk memperoleh penetapan.

\section{Musyawarah Masyarakat}

Pihak yang terlibat dalam proses ini adalah polisi, pelaku dan/atau orangtua/ walinya, korban dan/atau orangtua/walinya, pembimbing kemasyarakatan dan masyarakat (tokoh masyarakat atau dari pihak sekolah). Jenis tindak pidana yang dapat diselesaikan melalui musyawarah masyarakat ini adalah tindak pidana yang ancaman pidananya di bawah 7 (tujuh) tahun dan bukan pengulangan tindak pidana.
Pertemuan ini dimulai dengan memberikan kesempatan kepada pelaku untuk memaparkan bagaimana tindak pidana itu dilakukan dan atas dasar apa tindak pidana itu dilakukan. Pihak pelaku yang melakukan pemaparan sangat mengharapkan pihak korban untuk dapat menerima dan memahami kondisi dan penyebab mengapa pihak pelaku melakukan tindak pidana yang menyebabkan kerugian pada korban. Selanjutnya dalam penjelasan pelaku juga memaparkan tentang bagaimana dirinya bertanggung jawab terhadap korban dan masyarakat atas perbuatan yang telah dilakukannya. Selama pihak pelaku memaparkan tentang tindakan yang telah dilakukannya dan sebab-sebab mengapa sampai tindakan tersebut dilakukan pelaku, pihak yang lain terutama korban wajib mendengarkan dengan teliti penjelasan pelaku. Untuk selanjutnya pihak korban dapat memberikan tanggapan atas penjelasan pelaku. Korban menceritakan pengalaman yang dialaminya akibat kejahatan tersebut dan apa yang menjadi kerugian fisik, emosional, dan materi pada dirinya. Selain itu juga hadir pihak masyarakat yang mewakili kepentingan masyarakat. Wakil masyarakat tersebut memberikan gambaran tentang kerugian yang diakibatkan oleh telah terjadinya tindak pidana yang dilakukan oleh pelaku. Dalam paparannya tersebut masyarakat mengharapkan agara pelaku melakukan suatu perbuatan atau tindakan untuk memulihkan kembali keguncangan/kerusakan yang telah terjadi karena perbuatannya. Di sinilah terjadi 
suatu ikatan sosial antara pelaku tindak pidana dengan masyarakat. Hal ini sesuai dengan teori kontrol sosial Hirschi yang menyebutkan ada empat elemen ikatan sosial yang terdapat dalam setiap masyarakat, yaitu attachment, commitment, involvement, dan beliefs.

Elemen attachment dapat diwujudkan melalui keikutsertaan masyarakat dalam pelaksanaan diversi. Sepanjang seseorang memiliki hubungan erat dengan orang-orang penentu tertentu yang sangat penting, maka ia akan menghormati norma-norma mereka dan mengambil alih norma-norma itu. Dalam konteks ini pelaku dan keluarganya harus bisa melepas rasa ego dalam dirinya sehingga yang muncul adalah rasa kebersamaan. Rasa kebersamaan ini kemudian mendorong pelaku dan keluarganya untuk mentaati hasil kesepakatan, sebab jika melanggar berarti menyakiti korban dan masyarakat. Hubungan yang lahir antara pelaku dan korban tidak didasarkan pada peleburan ego tetapi karena hadirnya orang lain yang mengawasi. Dengan demikian, maka akan mencegah keinginan pelaku dan keluarganya untuk melakukan pelanggaran atas kesepakatan yang telah dibuat dan menciptakan kepatuhan ketika ada orang lain yang mengawasi. Eleman Commitment adalah keterikatan seseorang pada sub-sistem konvensional seperti sekolah, pekerjaan, organisasi dan sebagainya. Commitment merupakan aspek rasional yang ada dalam ikatan sosial. Segala kegiatan yang dilakukan oleh seseorang (sekolah, pekerjaan, organisasi dan sebagainya) akan mendatangkan manfaat bagi orang tersebut. Dalam konteks ini perlu keterlibatan pihak sekolah atau organisasi di lingkungan pelaku untuk memberikan manfaat. Manfaat tersebut dapat berupa harta benda, reputasi, masa depan dan sebagainya. Segala investasi tersebutlah yang akan mendorong pelaku dan keluarganya untuk taat pada kesepakatan yang telah dibuat. Jika mereka tidak taat pada hasil kesepakatan, maka segala investasi yang diperoleh akan lenyap begitu saja. Dengan demikian sesungguhnya invenstasi tersebut dapat digunakan sebagai kontrol bagi keinginan untuk melakukan penyimpangan. Elemen involvement mengacu pada suatu pemikiran bahwa apabila pelaku disibukkan atau berperan aktif dalam berbagai kegiatan konvensional atau pekerjaan maka ia tidak akan sempat berpikir apalagi terlibat dalam perilaku menyimpang. Logika dari pengertian ini adalah jika orang aktif di segala kegiatan, maka orang tersebut akan menghabiskan waktu dan tenaganya dalam kegiatan tersebut. Sehingga dia tidak sempat lagi memikirkan hal-hal yang bertentangan dengan hukum. Dengan demikian, maka segala aktivitas yang dapat memberi manfaat akan mencegah seseorang untuk melakukan perbuatan yang bertentangan dengan hukum. Elemen beliefs mengacu pada kepercayaan atau keyakinan pelaku pada nilai atau kaidah kemasyarakatan yang berlaku. Kepercayaan terhadap norma atau aturan yang ada akan sangat mempengaruhi seseorang bertindak mematuhi atau melawan peraturan yang ada. Anak yang secara jelas mengetahui nilai-nilai 
norma yang telah ditanamkan oleh masyarakat akan selalu dijadikan alat kontrol dalam setiap tindakannya. Penanaman nilai-nilai moral sejak dini akan selalu melekat dan akan selalu tertanam dalam diri anak. Salah satu nilai moral yang harus ditanamkan kepada anak yang melakukan tindak pidana adalah nilai tanggung jawab. Anak harus mempunyai tanggung jawab atas setiap perbuatan yang dilakukannya, apalagijika akibat perbuatannya itu menimbulkan kerugian bagi orang lain.

Bentuk sanksi yang dapat diberikan pada pelaku dalam musyawarah masyarakat ini adalah:

1. Menyerahkan kembali kepada orangtua/ walinya;

b. Permintaan maaf kepada korban dimuka umum;

3. Rehabilitasi medis dan psikososial;

4. Perbaikan akibat tindak pidana

5. Pembayaran ganti rugi;

6. Pelayanan masyarakat;

7. Menyerahkan kepada lembaga sosial pemerintah atau swasta untuk mengikuti pendidikan dan pelatihan;

8. Bentuk lainnya yang sesuai dengan kasus yang terjadi.

\section{Simpulan}

Konsep prosedur pelaksanaan diversi pada tahap penyidikan dalam penyelesaian tindak pidana yang dilakukan oleh anak terdapat tiga bentuk, yaitu: Pertama, Musyawarah Polisi. Para pihak hanya terdiri dari polisi dan pelaku. Jenis tindak pidananya pelanggaran dan tindak pidana ringan. Sanksinya berupa peringatan informal, yaitu peringatan lisan dan peringatan tertulis. Peringatan informal tersebut tidak dicatat dalam suatu kesepakatan dan tidak perlu dimintakan penetapan ke pengadilan negeri. Kedua, Musyawarah Keluaga. Para pihak yang terlibat adalah polisi, pelaku dan/atau orangtua/walinya, dan pembimbing kemasyarakatan. Jenis tindak pidananya adalah tindak pidana ringan, tindak pidana tanpa korban dan tindak pidana yang nilai kerugian korban tidak lebih dari nilai upah minimum propinsi setempat. Sanksinya berupa peringatan formal yang dicatat dalam buku catatan kepolisian tapi tidak perlu disampaikan ke Pengadilan Negeri. Ketiga, Musyawarah Masyarakat. Para pihak yang terlibat adalah polisi, pelaku dan/atau orangtua/walinya, korban dan/ atau orangtua/walinya dan pembimbing kemasyarakatan serta masyarakat. Jenis tindak pidananya adalah tindak pidana yang diancam dengan pidana penjara di bawah 7 (tujuh) tahun dan bukan pengulangan tindak pidana serta bukan masuk kategori tindak pidan berupa pelanggaran, tindak pidana ringan, tindak pidana tanpa korban dan tindak pidana yang nilai kerugian korban tidak lebih dari nilai upah minimum propinsi setempat. Sanksinya berupa peringatan formal yang harus mendapatkan persetujuan dari korban dan/atau keluarganya jika korban masih di bawah umur. Hasil musyawarah itu kemudian dituangkan dalam sebuah kesepakatan diversi yang ditandangtangani oleh para 
pihak. Kemudian hasil kesepakatan diversi itu disampaikan oleh atasan langsung polisi kepada Pengadilan Negeri untuk memperoleh penetapan. Setelah menerima penetapan dari pengadilan, Penyidik menerbitkan surat penetapan penghentian penyidikan.

\section{DAFTAR PUSTAKA}

Adi, Koesno, 2009, Diversi Sebagai Upaya Alternatif Penanggulangan Tindak Pidana Narkotika Oleh Anak, UMM Press, Malang.

dalam Sistem Peradilan Pidana
yang Berorientasi pada Kepentingan
Terbaik Bagi Anak, Pidato
Pengukuhan Jabatan Guru Besar dalam
bidang Ilmu Hukum Pada Fakultas
Hukum Universitas Brawijaya Malang.
Hadisuprapto, Paulus, 2006, Peradilan

Restotarif: Model Peradilan Anak Indonesia Masa Datang, Pidato Pengukuhan Guru Besar dalam Bidang Kriminologi pada Fakultas Hukum Universitas Diponegoro, Semarang.

Anak: Pemahaman dan
Penanggulangannya, Bayumedia Publishing, Malang.

Tim KPAI: Indonesia Negara Terbanyak Memidana Anak. Kompas, 16 Juli 2009.

Sulistiyono, Adi, 2005, Rasionalkan Budaya Musyawarah Untuk
Mengembangkan Penggunaan Penyelesaian Sengketa Win-Win Solution, Orasi Ilmiah Dalam Rangka Dies Natalis XXIX Universitas Sebelas Maret Disampaikan Pada Sidang Senat Terbuka Universitas Sebelas Maret Tanggal 12 Maret 2005.

Republik Indonesia Undang-Undang tentang Kitab Undang-Undang Hukum Acara Pidana, UU Nomor 8 Tahun 1981.

Republik Indonesia, Undang-Undang tentang Pengadilan Anak, UU Nomor 3 Tahun 1997 Lembaran Negara Republik Indonesia Tahun 1997 Nomor 3, Tambahan Lembaran Negara Republik Indonesia Nomor 3668.

Republik Indonesia, Undang-Undang tentang Sistem Peradilan Pidana Anak. UU Nomor 11 Tahun 2012, Belum dalam bentuk lembaran lepas.

Resolusi PBB A/RES/40/33 Tahun 1986 tentang United Nations Standard Minimum Rules for the Administration of Juvenile Justice ("The Beijing Rules"). 